Jpn. J. Limnol., 48, 2, 117-126, 1987.

\title{
Life History and Reproduction of Jesogammarus spinopulps (Anisogammaridae: Amphipoda) Inhabiting a Lowland Pond in Tokyo City
}

\author{
Harumi Kusano, Tamotsu Kusano and Yasunori Watanabe
}

\begin{abstract}
Jesogammarus spinopulps MORINo (Anisogammaridae) is one of the freshwater amphipods endemic to Japan. The life history and reproduction of this species were studied in a small lowland pond in Tokyo. J. spinopulps bred in winter and the life cycle was annual. The growth rate of juveniles was retarded from May to August in the field, and the laboratory experiment indicated that it was partly due to high water temperature $\left(>25^{\circ} \mathrm{C}\right)$. The high temperature $\left(25^{\circ} \mathrm{C}\right)$ accelerated only the growth of newborn juveniles, but repressed the growth rate of larger juveniles, maturity and survival. Juveniles began to develop sexual characteristics from October, and males became significantly larger than females prior to maturity. Reproduction occurred in a cold season from late December to early May, and a female yielded three or four clutches. The reproduction of $J$. spinopulps is the typical "many small egg" type as compared to other lotic and marine species of similar size. Such a reproductive type may be advantageous in environments where anisogammarids are exposed to harmful high temperature in summer and constrained to breed within a limited period.
\end{abstract}

Key words : Jesogammarus spinopulps, life history, growth, reproduction.

\section{Introduction}

The genus Jesogammarus is regarded as the one endemic to Japan, and belongs to the Family Anisogammaridae which is distributed in the North Pacific region. Several species of this genus have been described by Morino (1984, 1985). Jesogammarus inhabits various freshwater environments such as spring brooks, mountain streams, river, lakes and marshes. Each anisogammarid in these habitats is characterized by its morphology, behavior and ecology. The differences in these characteristics may reflect adaptive response to the environments where they live. Thus, it is very interesting to compare their life history and reproductive patterns. However, there is now little information on these aspects of Jesogammarus. We need information especially on growth pattern, mature size, breeding behavior and reproductive parametrs such as egg size, clutch size and clutch frequency.

In the present study, we report life history and reproductive type of Jesogammarus spinopulps MORI. No. This species inhabits small lowland ponds and marshes of the Kanto district, where drastic seasonal changes occur in water temperature, food amount and predation pressure as compared to those in other habitats.

\section{Study site}

Field surveys were performed every month from April 1984 to August 1986 in the National Park for Nature Study in Tokyo. There are two water courses in the west and east parts of this park, which flow into a common outlet to a sewer. J. spinopulps was collected in the west course, which consists of some small ponds and water channels. The water is supplied by ground and rain water, and the bottom substrate is red loam covered by sapropel. The collection sites are surrounded by dense vegetation of various trees. The litter of deciduous trees falls into the water from October to December, and that of evergeen trees in May, every year. The water is eutrophicated by litter decomposition, and the $\mathrm{pH}$ value was 6.8-7.5. It contains a large amount of inorganic ions such as $\mathrm{C}_{\mathrm{a}}{ }^{2+}\left(20-36 \mathrm{mg} \ell^{-1}\right), \mathrm{Mg}^{2+}(9$ $\left.-12 \mathrm{mg} \ell^{-1}\right), \mathrm{Na}^{+}\left(12-26 \mathrm{mg} \ell^{-1}\right), \mathrm{Cl}^{-}\left(21-28 \mathrm{mg} \ell^{-1}\right)$ and $\mathrm{K}^{+}\left(2.5-8.5 \mathrm{mg} \ell^{-1}\right.$ ) (HISAI et al. 1974 ; SAKAGAMI et al. 1984). 


\section{Methods and materials}

\section{3-1. Sampling}

Animals were collected about midday by scooping with a fine stramin hand-net. In anisogammarids, a mature male guards a female by holding onto her back for some time before copulation (precopula pair). Of the collected breeding animals, each precopula pair was kept in a $3 \mathrm{~m} \ell$ bottle at the site. All the breeding adults were brought to the laboratory in live condition. Juveniles, collected after April 1985, were fixed in about $50 \%$ ethanol at the site.

\section{3-2. Body length and sex}

The body length from the base of the first antenna to that of a telson was measured to the nearest 0.1 $\mathrm{mm}$ by straightening out each animal and using an ocular micrometer of a stereoscopic microscope ( $x$ 6.6-20). The living animals were measured after anesthetization by bubbling $\mathrm{CO}_{2}$ gas for a few seconds in a small petri dish. Animals were grouped into $0.2 \mathrm{~mm}$ length classes. The sex of each individual was determined by the presence of oostegites for females and genital papillae for males. They were regarded as mature when females had developed oostegites larger than $1.0 \mathrm{~mm}$ and males had been armed with peg spines on the palmar margins of the first and second gnathopods. Almost all mature females developed oocytes in ovaries and/or carried eggs (embryos and hatchlings) in their brood pouches.

\section{3-3. Growth and survival experiment}

To examine the effect of water temperature on juvenile growth and survival, rearing experiment was conducted. Materials proposed for the experiment were juveniles released at $20^{\circ} \mathrm{C}$ from 6 to 12 April 1984. The experiment was started on 5 May to incubate them under four temperature regimes : $10,15,20$ and $25^{\circ} \mathrm{C}$. Juveniles less than about $4 \mathrm{~mm}$ in body length were reared in petri dishes $(8 \mathrm{~cm}$ in diameter) containing $30 \mathrm{~m} \ell$ of pond water and five pieces $(2 \mathrm{~cm} \times 2 \mathrm{~cm} /$ piece $)$ of decaying leaves of Idesia polycarpa, which were renewed once a week. Juveniles larger than about $4 \mathrm{~mm}$ were reared in plastic boxs $(12 \mathrm{~cm} \times 11 \mathrm{~cm} \times 5 \mathrm{~cm})$ with $150 \mathrm{~m} \ell$ of water and ten pieces of decaying leaves. In the last week of every month, the survivors were counted and their body length was measured.

\section{3-4. Clutch size and egg volume}

Precopula pairs collected from the field were incubated until oviposition under three temperature regimes : 5, 10 and $15^{\circ} \mathrm{C}$. Each pair was reared in a small plastic vessel containing $50 \mathrm{~m} \ell$ of pond water, decaying leaves of Idesia polycarpa (two pieces of 2 $\mathrm{cm} \times 2 \mathrm{~cm}$ ) and artificial food for Malacostraca (about $3 \mathrm{mg}$ in dry weight). Water and food were renewed once a week. Within a day after oviposition, the ovigerous female was anesthetized by bubbling $\mathrm{CO}_{2}$ gas to measure the number and size of eggs. Since the shape of an egg was nearly ellipsoidal, the major (a) and minor (b) axes were measured to the nearest $0.025 \mathrm{~mm}$ using an ocular micrometer. The single egg volume was calculated as (4/3) $\pi \mathrm{ab}^{2}$. More than 15 eggs were measured for one clutch to determine mean single egg volume. The clutch volume was estimated by multiplying mean single egg volume by clutch size.

\section{Results}

\section{4-1. Life history}

Before the summer of 1984, J. spinopulps showed a high population density in the ponds and water channels of the upper west water course. However, it became difficult to collect a sufficient number of animals after a drastic drought from August to November 1984, when the major habitats, the littoral zone of the upper reaches, had dried up. After April 1985, animals of all ages were collected from the lower reaches, where the density was comparatively high. The water temperature in the submerged litter layer at collection was shown in Figure 1 with maxima and minima between surveys. These values were measured by a maximum-minimum thermometer which was kept in the water. The water temperature was higher than $25^{\circ} \mathrm{C}$ in summer but lower than $5^{\circ} \mathrm{C}$ in winter. The maximum and minimum temperatures in the summer of 1985 were estimated from the past five years' data.

Figure 2 shows the seasonal change in body length, in which the data of juveniles smaller than $5 \mathrm{~mm}$ before March 1985 were not plotted because of non -random sampling. The life cycle of $J$. spinopulps is clearly annual, and the breeding season was limited for about 4.5 mon in winter, usually from late December to early May. Before maturity, the mean body length of males became significantly greater than that of females ( $t=4.358$, df $47, P<0.001$ in November 1985). The mean sexual size ratio (male/female) was 1.09 for all mature individuals. Almost all females were in precopula and/or carrying eggs in breeding seasons. There was little growth of breeding individuals, and all adults died 


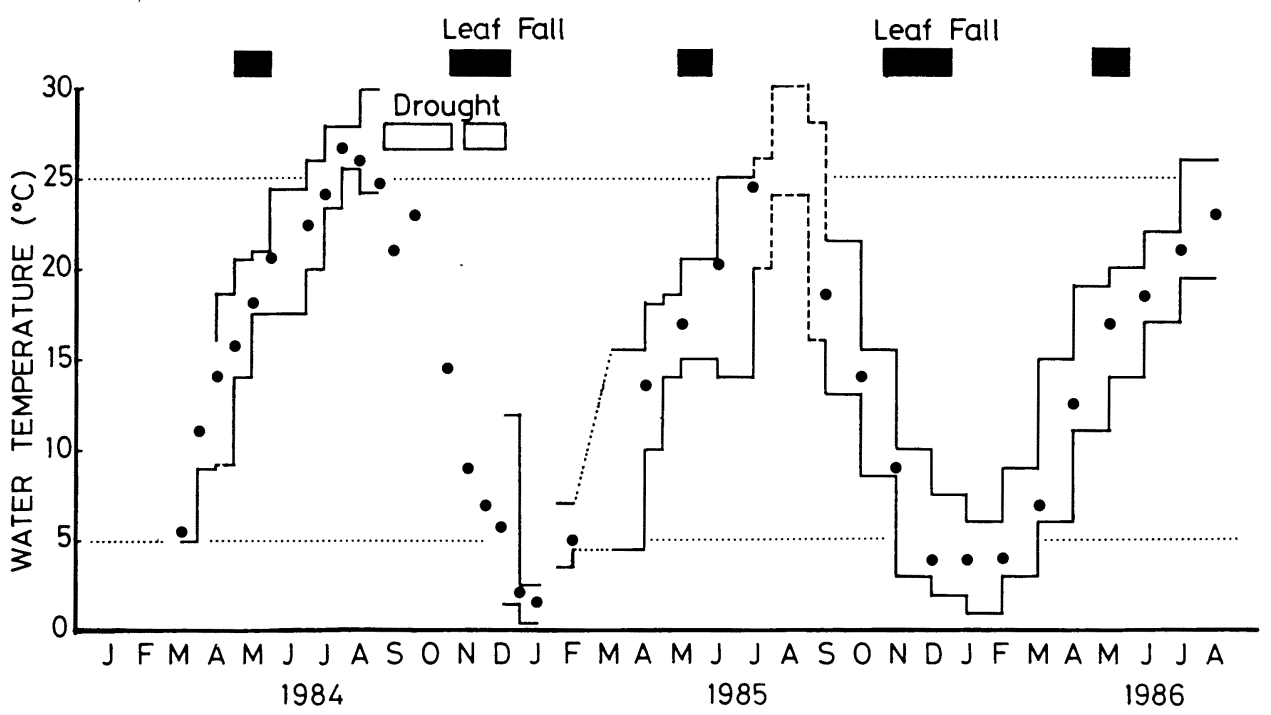

Fig. 1. The water temperature at the collection site. The black circle shows the temperature at a sampling time while the solid line means the maxima and minima between surveys; The broken line in the summer of 1985 was that estimated from the previous five-year data.

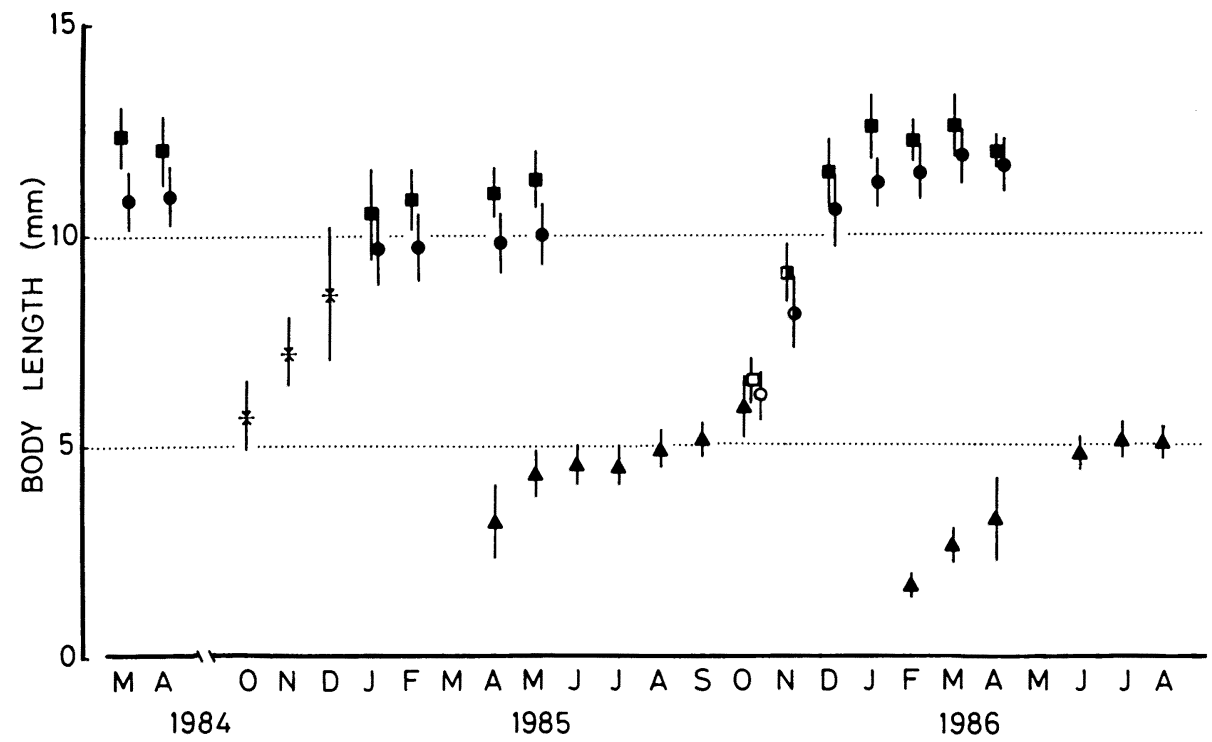

Fig. 2. Temporal variation of mean body length of $J$. spinopulps (with SD). The size of juveniles smaller than $5 \mathrm{~mm}$ is not plotted before March 1985. Asterisks indicate the mean body length of both juveniles and immature individuals which are collected various sites in the west water course during a drought.

by early May. In the autumn of 1984, the growth rate was so slow due to a drought that they could not mature by late December 1984, and the breeding adults in the winter of 1985 were significantly smaller in both sexes than in the winters of 1984 and 1986 (by KrL'SKaL-Wallis test, $d f 2, P^{\prime} s \ll 0.001$ ).
Newborn juveniles (about $1.2 \mathrm{~mm}$ in body length) appeared in the field from early February to early May. Figure 3 shows the size frequency distribution of juveniles collected from the spring to the early summer of 1985 and 1986. A large variation in their size was observed in April, since the juveniles born in 


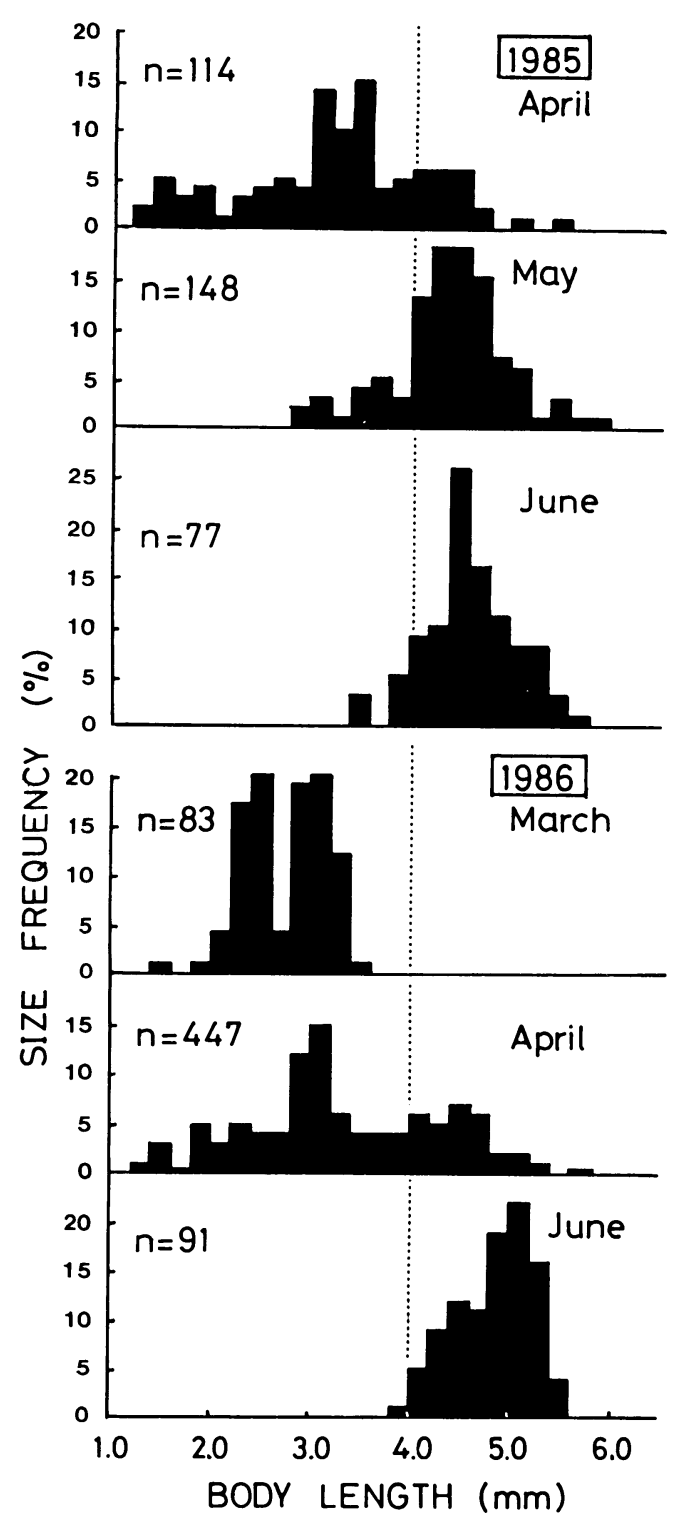

Fig. 3. Size frequency distribution of juveniles from spring to early Summer in 1985 and 1986.

the earlier period grew to more than $4 \mathrm{~mm}$ by then. In the late breeding seasons, there were three or four peaks in the size distribution of juveniles, although these peaks were not so clear. This implies that a female laid eggs about three times during a breeding season, and that the oviposition was roughly synchronous. After the breeding seasons, the juveniles hardly grew from May to August (Fig. 2), while their size variation became smaller to show one-peak distributions (Fig. 3). Such a size distri- bution did not change markedly until October when the sexual differentiation began.

In April, there was no difference in the mean size of juveniles between 1985 and 1986 ( $t=0.902$, df 559, $P>0.20$ ), but thereafter the juveniles grew significantly larger in 1986 than in 1985 ( $t=3.585, d f$ $166, P<0.001$ in June, $t=9.864$, df $365, P<0.001$ in July). This is probably because the water temperature in 1986 did not rise so high until July due to the delay in the rainy season.

\section{4-2. Effect of temperature on growth rate and survival}

Figure 4 shows the growth curves for four regimes of water temperature. Experiments were started with juveniles of $1.6 \mathrm{~mm}$ in mean body length. In the first 50 days, the growth rates at $20^{\circ} \mathrm{C}$ and $25^{\circ} \mathrm{C}$ were so high that their mean length approached 4 $\mathrm{mm}$, against a smaller $2.5 \mathrm{~mm}$ at $10^{\circ} \mathrm{C}$. However, in the following 100 days, the growth rate decreased at $25^{\circ} \mathrm{C}$. Figure 5 shows the relationship between temperature and arithmetic specific growth rate $\left(G_{a}: \Delta\right.$ $\mathrm{L} / \Delta \mathrm{t}, \%$ day $\left.^{-1}\right)$. The $G_{a}$ values of newborn juveniles were calculated while they grew from $1.6 \mathrm{~mm}$ (about 12 days after hatching) to $2.0-2.3 \mathrm{~mm}$ in mean body length. The durations required for the growth were 58 days at $10^{\circ} \mathrm{C}$ and 26 days at 15,20 and $25^{\circ} \mathrm{C}$. $G_{a}$ of larger animals was calculated while

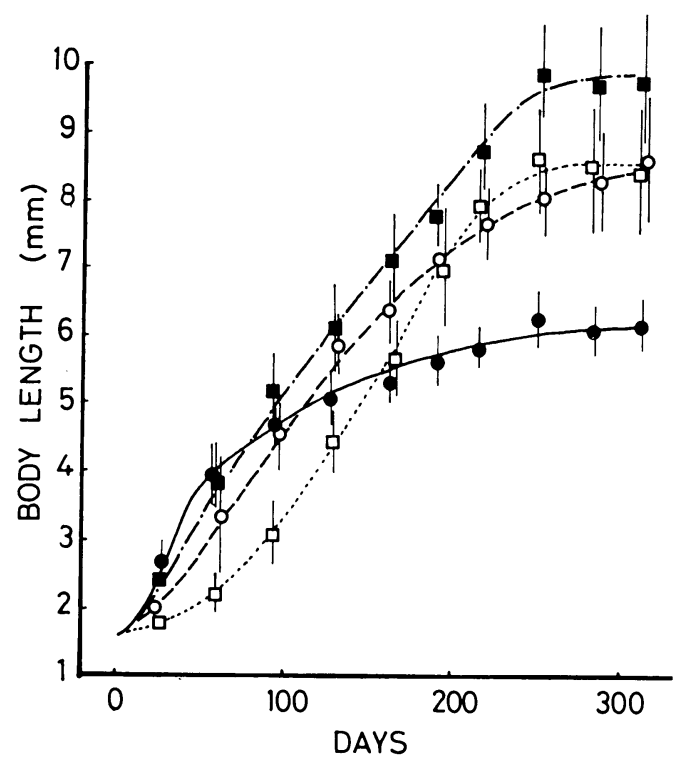

Fig. 4. Growth curves of J. spinopulps under four temperature regimes in laboratory The symbol and vertical line indicate mean \pm SD. $\left(\square: 10^{\circ} \mathrm{C}, \bigcirc\right.$ : $15^{\circ} \mathrm{C} \boldsymbol{\square}: 20^{\circ} \mathrm{C},: 25^{\circ} \mathrm{C}$ ) 


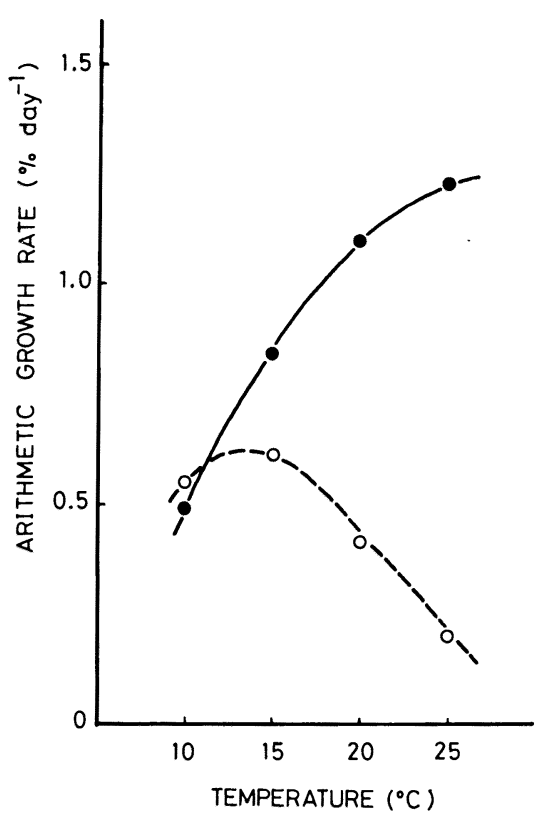

Fig. 5. Arithmetic mean growth rates $\left(G_{\mathrm{a}}: \Delta L / \triangle\right.$ $t, \%$ day $\left.^{-1}\right)$ for newborn $($ from $1.6 \mathrm{~mm}$ to 2 . $0-2.3 \mathrm{~mm}$ in mean body length) and larger juveniles $(O:$ from $4.0-4.5 \mathrm{~mm}$ to $5.6-5.9$ $\mathrm{mm}$ ) of $J$. spinopulps. Curves were fitted by eye. their length increased from $4.0-4.5 \mathrm{~mm}$ to $5.6-5.9$ $\mathrm{mm}$. The durations were 36 days at $10^{\circ} \mathrm{C}, 38$ days at $15^{\circ} \mathrm{C}, 73$ days at $20^{\circ} \mathrm{C}$ and 135 days at $25^{\circ} \mathrm{C}$. The curvilinear relationship between $G_{a}$ and temperature indicates that the optimal temperature for the growth of newborn juveniles (above $20^{\circ} \mathrm{C}$ ) was higher than that of juveniles larger than $4 \mathrm{~mm}$ (between 10 and $15^{\circ} \mathrm{C}$ ). Reproduction was initiated after the 200 th day at 10,15 and $20^{\circ} \mathrm{C}$, but was not observed by the 300 th day at $25^{\circ} \mathrm{C}$. Thus, water temperature of $25^{\circ} \mathrm{C}$ inhibited maturity. The survival rate (number of survivors/initial number of individuals) is shown in Table 1 . The mortality in the early stage was higher at 25 and $20^{\circ} \mathrm{C}$ than at the lower temperatures. On the 50th day, survial rate at $10^{\circ} \mathrm{C}$ was three times as high as at $25^{\circ} \mathrm{C}$. From the viewpoint of survival, water temperature higher than $25^{\circ} \mathrm{C}$ was an aggravating condition for the newborn juveniles.

\section{4-3. Reproductive parameters}

Table 2 shows precopula duration under three temperature regimes $\left(5,10\right.$ and $\left.15^{\circ} \mathrm{C}\right)$ estimated by multiplying the mean days from collection to oviposition by 2 (see WARD, 1985). The precopula duration from December to February approached a month in the field. From the precopula duration at different temperatures, the maximal number of

Table 1. Survivorship of $J$. spinopulps under four temperature regimes in laboratory.

\begin{tabular}{cccc}
\hline $\begin{array}{c}\text { Water } \\
\text { temperature }\end{array}$ & $\begin{array}{c}\text { Initial number } \\
\text { of individuals }\end{array}$ & \multicolumn{2}{c}{ Survival (\%) } \\
50 th day & 250 th day \\
\hline $10^{\circ} \mathrm{C}$ & 50 & 75 & 50 \\
$15^{\circ} \mathrm{C}$ & 102 & 69 & 64 \\
$20^{\circ} \mathrm{C}$ & 92 & 40 & 36 \\
$25^{\circ} \mathrm{C}$ & 80 & 26 & 21 \\
\hline
\end{tabular}

Table 2. Days from collection to oviposition and expected precopula duration at different water tempratures. Precopula pairs were reared at the water temperature approximating that when they were collected ; January and February 1985 (six times) at $5^{\circ} \mathrm{C}$; December 1985 and February 1986 (two times) at $10^{\circ} \mathrm{C}$; April and May 1985 (four times) at $15^{\circ} \mathrm{C}$.

\begin{tabular}{cccc}
\hline $\begin{array}{c}\text { Water } \\
\text { temperature }\end{array}$ & $n$ & $\begin{array}{c}\text { days(sampling-oviposition) } \\
\text { mean } \pm \mathrm{SD}\end{array}$ & $\begin{array}{c}\text { Expected precopula } \\
\text { duration (days) }\end{array}$ \\
\hline $5^{\circ} \mathrm{C}$ & 68 & $13.22 \pm 9.65$ & 26.5 \\
$10^{\circ} \mathrm{C}$ & 34 & $7.56 \pm 5.32$ & 15.1 \\
$15^{\circ} \mathrm{C}$ & 25 & $4.52 \pm 3.36$ & 9.0 \\
\hline
\end{tabular}


clutches per female was estimated to be about four in the field. This result agrees with the size distribution of juveniles in April as mentioned above. The mean number of clutches per female should be determined by a further experiment on the developmental time of embryos.

All or a part of eggs in clutches of some females were abnormal. They were larger than the normal ones, and could neither divide nor develop into normal embryos. Some females brought oligochaetes in their brood pouches. WARD (1985) reported the harmful effect of parasitic oligochaetes on the reproduction of Gammarus duebeni, but this has not been known in J. spinopulps. Abnormal eggs and females bringing oligochaets were excluded from the analysis of clutch parameters.

Figure 6 shows the relationships of clutch size and clutch volume to female length. A strong positive correlation was detected for both cases $(r=0.790$, $P<0.001$ for clutch size and $r=0.813, P<0.001$ for clutch volume). These two parameters were nearly proportional to the third power of female length $(i$. $e$, female volume). It suggests that clutch size and clutch volume are limited by the size of the female body cavity. On the other hand, there is no significant correlation between single egg volume and female length $(r=0.122)$ (Fig. 7).

\section{Discussion}

\section{5-1. Growth retardation in summer}

In J. spinopulps, juvenile growth was retarded from May to August (Fig. 2), and the high water temperature in summer $\left(>25^{\circ} \mathrm{C}\right)$ is indicated to be one of the important factors causing growth retardation by the laboratory experiment. The optimal temperature for the growth of newborn juveniles $\left(20-25^{\circ} \mathrm{C}\right)$ was higher than that of juveniles larger than $4 \mathrm{~mm}$ (10 $-15^{\circ} \mathrm{C}$ ) (Fig. 5). It agreed with the case of Gammarus pulex (StTcliffe et al., 1981). The high temperature $\left(>20^{\circ} \mathrm{C}\right)$ accelerated the growth of newborn juveniles but was unfavorable for them because of high mortality. The change in size distribution of juveniles from April to June (Fig. 3) probably resulted from high mortality of newborn juveniles and repression in growth of larger juveniles. Since most species of the family Anisogammaridae are distributed throughout a high-latitude region of the North Pacific (Bousfield, 1979), it is probable that a similar phenomenon occurs in other species in the environments with high summer temperature. Nevertheless, this species was more tolerant of high

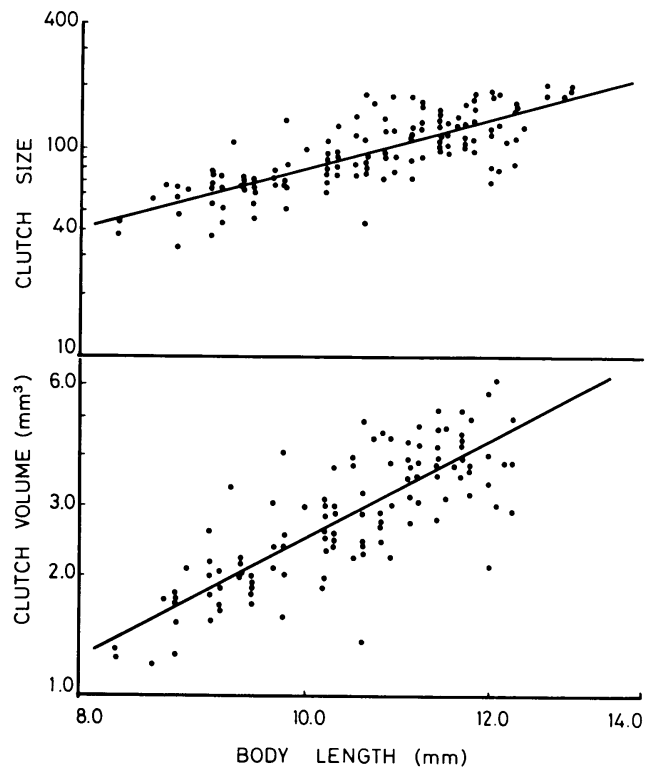

Fig. 6. Relationship between body length of a female and clutch size, clutch volume in $J$. spinopulps. Clutch size and clutch volume $(y)$ were significantly correlated with body length of a female $(x)$. The regression equations are $\log$ $(y)=3.024 \log (x)-1.120(r=0.790, d f=142$, $P<0.001)$ for clutch size, and $\log (y)=3.078 \mathrm{log}$ $(x)-2.686(r=0.813, d f=107, \quad P<0.001)$ for clutch volume.

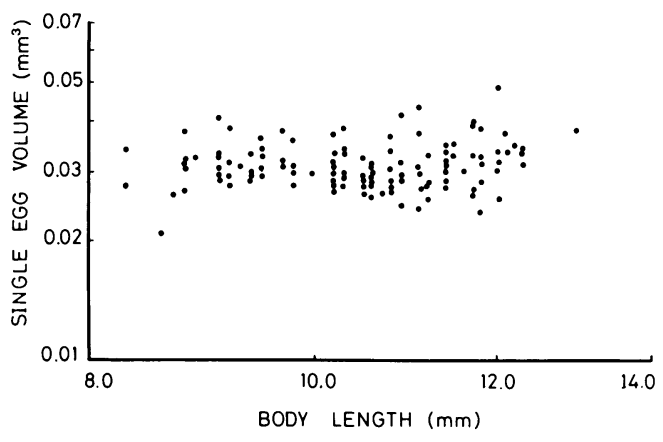

Fig. 7. Relationship between body length of a female $(x)$ and single egg volume $(y)$ in $J$. spinopulps ( $r=0.122, d f=126$, no significant).

temperature than other lotic species of Gammarus (MARCHANT, 1981) and Jesogammarus (Hamashima and Morino, 1984). Some studies on the relationship between water quality and growth or inhabitancy of freshwater Gammarus have indicated that the tolerance of high temperature required the relatively high concentration of inorganic ions relating to 
water hardness (SAvage, 1982 ; OKLAND and OKLAND, 1985).

From the reports on geographic distribution of $J$. spinopulps, the habitat of this species is limited to lakes near the sea (brackish water) and springs of hard ground water (Morino, 1985 ; KANEDA et al., 1986 ; NoZAKI, 1983). This suggests that the tolerance for high temperature in the present species depends on high water hardness of habitat. In lentic anisogammarids, J. naritai has been reported to withstand high temperature in summer near the shores of Lake Biwa (NARITA, 1976, described as an inshore type). Thus, high temperature from July to August can be one of the important factors affecting growth and survival in the life history of $J$. spinopulps.

However, retardation in growth occurred from May, when water temperature was lower than $20^{\circ} \mathrm{C}$, suggesting that certain other factors repressed their growth in addition to high temperature; for example, one may cite: (1) Food shortage. J. spinopulps feeds on decaying leaves of tender mesophyll (Idesia polycarpa, Cornus controversa, etc.), microbenthos (oligochaetes, nematodes, etc.), and some microalgae. Its primary food is decaying leaves, particularly among juveniles. The leaf litter of preference is supplied into the water every autumn, and is usually exhausted by mid-May. Juveniles could not grow in summer even if the water temperature were favorable. (2) Predation. Predators of the juveniles in this field were a benthic fish (Rhinogobius brunneus Temminck et Schlegel), a crayfish (Procambarus clarkii GIRARD) and a prawn (Paraemon paucidens DE HAAN). The observation in the laboratory showed that these predators could hardly catch adult anisogammarids but nabbed juveniles easily, and groping of crustacean predators frequently disturbed the resting and foraging of juveniles, probably repressing their growth. However, the effect of predators on the size distribution of juveniles is yet unknown. (3) An anaerobic condition. The sapropel on the bottom mud became anaerobic and sulfate reduction occurred from late April. Oxygen deficiency forcibly evicts the juveniles from their refuge on the bottom, and constrains them to aggregate within a limited space ( $i$. e., patch distribution). This makes them fairly easy prey for predators. In addition, starvation and aggregation eventually lead to cannibalism, which was often observed in the laboratory.

\section{5-2. Advantages of winter-breeding}

The life cycle of this species can be easily changed in the laboratory. Time to maturity was prolonged to more than 15 mon under the condition of poor food supply at $20^{\circ} \mathrm{C}$, whereas the juveniles collected in May matured to breed in September with sufficient artificial food supply at $15^{\circ} \mathrm{C}$. Life span was more than two years at $10^{\circ} \mathrm{C}$, and breeding individuals collected in early May could survive for more than half year to yield additional clutches at $10^{\circ} \mathrm{C}$. These facts indicate that its life cycle is controlled by seasonal change with the combination of factors mentioned above, and that Anisogammaridae may show an intraspecific variation of life history traits, as well as in Gammaridae (SKADSHEIm 1984 ; Doyle and Hunte 1981). Winter-breeding gives some advantages to J. spinopulps. (1) Juveniles can grow fast at a relatively high temperature and perhaps be more tolerant of water pollution in summer than adults (Hobrough, 1973). (2) Precopula pairs can avoid predation by carp, tortoises and other large predators which are active only at high temperature. This is probably a pattern characteristic of lentic environments (WARD, 1986).

From these speculations, freshwater amphipods in the temperate zone are expected to have winterbreeding in the habitats with drastic seasonal changes such as shallow ponds, marshes, small streams and lake shores. Conversely, they are expected to have semi-annual and biannual (two cycles in a year) life cycles in the habitats with moderate seasonal changes of environmental factors. Stanhope and Levings (1985) reported that a species of Anisogammaridae, Eogammarus confervicolus, could have both annual and biannual life cycles in different estuaries according to the food level within each habitat.

\section{5-3. Reproductive type}

Single egg volume varied little within a clutch (C. V. $<0.1$ ). A female divided her reproductive resources equally among eggs in a clutch. Clutch size and volume had a highly significant correlation with female length, and they were nearly proportional to female body volume. This fact suggests that clutch size and clutch volume are limited simply by size of the female body cavity. However, single egg volume showed no correlation with female length, and the values were scattered around 0.03 $\mathrm{mm}^{3}$. Single egg volume was determined by factors other than the female size.

Table 3 shows the reproductive types in various 
species of Jesogammarus and Gammarus of about 10 $\mathrm{mm}$ length in adult size. Clutch size is adjusted for $10 \mathrm{~mm}$ in female body length for interspecific comparison. Clutch size ranged from 11 to 78 , and egg volume from 0.031 to $0.133 \mathrm{~mm}^{3}$. The clutch size of $J$. spinopulps was the largest, whereas the single egg size $\left(0.03 \mathrm{~mm}^{3}\right.$ in volume, $0.4 \mathrm{~mm}$ in diameter) was the smallest. The reproduction of J. spinopulps is the typical "many small egg" type. Most species inhabit relatively cold regions where water temperature does not rise over $25^{\circ} \mathrm{C}$. The temperate species of Gammarus is semi-annual which increases its reproductive potential by repeating two generations in a year (WILDISH, 1982). For instance, the time to maturity is shortened and adult size is relatively small in $G$. lawrencianus and G. tigrinus. In addition, these two species produce relatively many eggs which are smaller than those of annual species. $J$. spinopulps, however, could not have a semi-annual life cycle due to harmful high temperature in sum. mer. Only the production of a large clutch of small eggs remained to increase the reproductive potential of this species. This may be why the eggs of $J$. spinopulps are smaller than those of semi-annual Gammarus species, although the adult size approaches that of northern annual species.

As to habitat types, reproductive types may be related to the amount of available food and survival rate of juveniles. The reproduction of the "many small egg" type has the advantage over that of the "few large egg" type in ponds and lakes, but the opposite is true in streams and rivers, since, in general, both food and predators in lentic environments are more abundant than in lotic environments (see ITO, 1978). At present, however, the factors determining the reproductive parameters of $J$.

Table 3. Reproductive type of various species of Jesogammarus and Gammarus. Habitat types are expressed by the following abbreviations ; F, freshwater ; B, brackish water ; $\mathrm{P}$, pond ; S, stream ; L, lake ; E, estuary ; SS, seashore. Clutch size is adjusted for $10 \mathrm{~mm}$ in female body length.

\begin{tabular}{|c|c|c|c|c|c|c|c|}
\hline Species & $\begin{array}{l}\text { Habitat } \\
\text { type }\end{array}$ & $\begin{array}{l}\text { Female } \\
\text { length } \\
(\mathrm{mm})\end{array}$ & $\begin{array}{l}\text { Clutch } \\
\text { size }\end{array}$ & $\begin{array}{l}\text { No. clutches } \\
\text { /generation }\end{array}$ & $\begin{array}{l}\text { Egg volume } \\
\quad\left(\mathrm{mm}^{3}\right)\end{array}$ & $\begin{array}{l}\text { Reproductive } \\
\text { season }\end{array}$ & References \\
\hline \multicolumn{8}{|l|}{$\langle$ annual $\rangle$} \\
\hline J. spinopulps & $\mathrm{F} \quad \mathrm{P}$ & $9-14$ & 78 & 3 & 0.031 & winter & (present study) \\
\hline J. paucisetulosus & $\mathrm{F} \mathrm{S}$ & $6-8$ & 11 & 3 & 0.054 & winter-spring & (unpublished data) \\
\hline \multirow[t]{3}{*}{ G. duebeni } & $\mathrm{B} \mathrm{S}$ & $9-12$ & 20 & $?$ & $?$ & winter & WARD (1985) \\
\hline & SS & & 17 & 3 & $0.093^{*}$ & winter & KoLDING and FENCHEL (1981) \\
\hline & SS & $10-19$ & 17 & 5 & 0.097 & summer & SteEl and SteEL (1975b) \\
\hline \multirow[t]{2}{*}{ G. oceanicus } & SS & $11-19$ & 20 & 3 & $0.099^{*}$ & winter & KOLDING and FENCHEL (1981) \\
\hline & SS & & 50 & $?$ & 0.089 & summer/winter** & STEEL and STEEL (1972a) \\
\hline G. pseudolimnaeus & $\mathrm{F} \quad \mathrm{S}$ & $9-14$ & 25 & 1 & $?$ & summer & MARCHANT and HYNeS (1981) \\
\hline G. obtusatus & SS & $9-14$ & 15 & 3 & 0.133 & summer/winter** & STEEL and STEEL (1970a) \\
\hline G. lacustris & $\mathrm{F} \quad \mathrm{L}$ & $9-14$ & 17 & $?$ & $?$ & spring & HyNES (1955) \\
\hline G. finmarchicus & SS & $10-18$ & 20 & 8 & 0.065 & all seasons & Steel and Steel (1975a) \\
\hline \multicolumn{8}{|l|}{$\langle$ semi-annual $\rangle$} \\
\hline G. pulex & $\mathrm{F} \mathrm{S}$ & $6-10$ & 20 & $6 ; 2^{* * *}$ & $?$ & - & Hynes (1955), WeLtoN (1979) \\
\hline G. lawrencianus & B E & $5-10$ & 20 & $7 ;$ ?*** & 0.045 & - & STEEL and SteEL (1970b) \\
\hline G. tigrinus & $\mathrm{F} \quad \mathrm{S}$ & $7-13$ & 30 & $7 ; 3^{* * *}$ & 0.051 & - & SteEl and STEEL (1972b) \\
\hline G. salinus & SS & $7-14$ & 30 & $7 ; 3^{* * *}$ & $0.056^{*}$ & - & KOLDING and FENCHEL (1981) \\
\hline
\end{tabular}

*: These values differ from the ones in the original paper. The correct values were directly informed by the authors.

**: A reproductive season differs between localities.

*** : No. of clutches per generation is shown for each generation of semi-annual species. 
spinopulps could not be discussed in detail because of the lack of information on other lentic species.

\section{Acknowledgments}

We would like to thank Mr. N. HiSAI, the National Institute of Nature Study, for allowing us to survey in the park and for his kind suggestion. We are grateful to Mr. T. HATANo for his assistance in the laboratory experiment.

\section{摘 要 \\ 東京都内低地池沼におけるアゴトゲョコエビ の生活史および繁殖}

Jesogammarus 属は淡水または汽水に分布する日本 固有のヨコエビであり，現在 7 種が記載されている。 これらは湖沼, 河川, 湧水など多様な環境に生息し, 種または生息場所のタイプによって異なった生活史や 繁殖様式をもつと思われる。本研究では関東近県の低 地止水に生息するアゴトゲョコエビJ. spinopulps の生 活史および産卵様式を約 2 年間にわたり調査した。調 査は 1984 年 3 月から 1986 年 8 月まで東京都港区自然 教育園において行なった。本種の寿命は約 1 年であ り、繁殖期は 12 月末から 5 月初旬であった。野外では 夏期（6月から8月）に幼体の成長遅滞がみられた。 この原因の一つに高水温 $\left(25^{\circ} \mathrm{C}\right.$ 以上) による幼体（特 に体長 $4 \mathrm{~mm}$ 以上の個体) の成長阻害があることが飼 育実験から明らかになった。9月以降幼体は急速に成 長し，10月頃から性的特徵を生ずるとともに雄は雌よ り有意に大きくなる。成熟した雌雄の体長比は約 1.09 であった。12月末から4月末まで番い（雄による雌の 交尾前防衛）が，また 1 月から 5 月初旬まで抱卵雌が 見られ，繁殖期後成体はまったくいなくなった。飼育 下における番い継続日数により, 繁殖期間中の 1 雌当 りの産卵回数は最大 4 回であることがわかった。抱卵 数と抱卵容積は雌の体長に高い正の相関を示したが, 一卵容積とは全く相関を示さずほぼ $0.03 \mathrm{~mm}^{3}$ と一定 であった。産卵様式を他のヨコエビと比較してみると 本種は著しく小卵多産的である。温帯域の多くのヨコ エビは水温の季節変化が比較的稳やかな河川や海水域 で一年に2 世代が繁殖できる（semi-annual life cycle)。これに対し, 本種は低地止水で夏期の高温に よる成長阻害や高い死亡率があるため，一年生（より 北方で見られる。annual 1. c.) を強いられている。小 卵多産型はこのことへの適応であると推測された。

\section{References}

Botsfield, E. L. (1979) : The Amphipod superfamily Gammaroidea in the northeastern Pacific region: Systematics and distributional ecology. Bull. Biol. Soc. Wash., No. 3, pp. 297-357.
Doyle, R. W. and W. Hunte (1981): Genetic changes in "fitness" and yield of a crustacean population in a controlled environment. J. exp. mar. Biol. Ecol., 52 : 147-156.

Hamashima, W. and H. Morino (1984): Experimental studies on the growth, survival, and breeding activities of Jesogammarus paucisetulosus Morino at different temperatures. Publ. Itako Hydrobiol. Stn., $1: 25-38$.

Hisai, N., T. Sugawara and N. Tanaka (1974): Report on the qualities of water at ponds and springs in the National Park for Nature Study. Rept. Inst. Nat. Stu., No. 5, pp. 1-7.

Hobrough, J. E. (1973): The effects of pollution on Gammarus pulex (L) subsp, pulex (Schellenberg) in the inlet streams of Rostherne Mere, Cheshire. Hydrobiologia, 41 : 13-35.

Hynes, H. B. N. (1955): The reproductive cycle of some british freshwater Gammaridae. J. Anim. Ecol., 24 : 352-387.

ITo, Y. (1978): Comparative Ecology. 2nd ed. Iwanami Press, Tokyo. (in Japanese)

Kaneda, S., N. Kobayashi, S. Fukushima, J. Hata KenakA, H. Mizuno and F. Higuchi (1986): Benthic fauna of streams in Yokohama, Japan. Benthic fauna. pp. 85-108. In Fauna and flora of streams and seas in Yokohama (4), Pollution data No. 126. Yokohama Pollution Control Bureau. (in Japanese)

Kolding, S. and T. M. Fenchel (1981): Patterns of reproduction in different populations of five species of the amphipod genus Gammarus. Oikos, 37 : 167-172.

Marchant, R. (1981): The ecology of Gammarus in running water. pp. 225-249. In M. A. Lock and D. D. William (ed.), Perspectives in Running Water Ecology. Plenum Press, NY.

Morino, H. (1984): On a new freshwater species of Anisogammaridae (Gammaroidea : Amphipoda) from central Japan. Publ. Itako Hydrobiol. Stn., 1 : 17-23.

Morino, H. (1985): Revisional studies on Jesogammarus- Annanogammarus group (Amphipoda: Gammaroidea) with descriptions of four new species from Japan. Publ. Itako Hydrobiol. Stn., 2 : 9-55.

NARITA, T. (1976): Occurrence of two ecological forms of Anisogammarus annandalei (Tattersall) (Crustacea: Amphipoda) in Lake Biwa. Physiol. Ecol. Japan, 17 : 551-556.

NozAKI, T. (1983): Bottom fauna in the Hirasaku 
River. pp. 143-145. In Aquatic Organisms in Kanagawa Prefecture, Kanagawa Prefecture Government. (in Japanese)

OKLAND, K. A. and J. OKLAND (1985): Factor interaction influencing the distribution of the freshwater "shrimp" Gammarus. Oecologia, 66 : 364-367.

Sakagami, K., Y. Seto and N. Hisai (1984): Seasonal changes in water qualities at ponds and springs in the Institute for Nature Study. Rept. Inst. Nat. Stu., No. 15, pp. 3-11.

Savage, A. A. (1982): The survival and growth of Gammarus tigrinus Sexton (Crustacea: Amphipoda) in relation to salinity and temperature. Hydrobiologia, $94:$ 201-212.

SkADSHEIM, A. (1984): Coexistence and reproductive adaptations of amphipods : the role of environmental hetelogeneity. Oikos, $43: 94-103$.

Stanhope, M. J. and C. D. Levings (1985) : Growth and production of Eogammarus confervicolus (Amphipoda: Anisogammaridae) at a Log Storage Site and in areas of undisturbed habitat within the Squamish Estuary, British Columbia. Can. J. Fish. Aquat. Sci., 42: 1733-1740.

Steele, D. H. and V. J. Steele (1970 a) The biology of Gammarus (Crustacea, Amphipoda) in the northwestern Atlantic. III. Gammarus obtusatus Dahl. Can. J. Zool., 48 : 989-995.

Steele, D. H. and V. J. Steele (1970 b) Ditto. IV. Gammarus lawrencianus Bousfield. Can. J. Zool., 48: 1261-1267.

Steele, V. J. and D. H. Steele (1972a) Ditto. V. Gammarus oceanicus Segerstrale. Can. J. Zool.,
50:801-813.

Steele, D. H. and V. J. Steele (1972b) Ditto. VI. Gammarus tigrinus Sexton. Can. J. Zool., 50 : 1063-1068.

Steele, D. H. and V. and V. J. Steele (1975a) Ditto. X. Gammarus finmarchicus Dahl. Can. J. Zool., $53: 1110-1115$.

Steele, D. H. and V. J. Steele (1975b) Ditto. XI. Comparison and discussion. Can. J. Zool., 53 : 1116-1126.

Sutcliffe, D. W., T. R. CArrick and L. G. Willolgh . BY (1981): Effects of diet, body size, age and temperature on growth rates in the amphipod Gammarus pulex. Freshwat. Biol., 11 : 183-214.

WARD, P. I. (1985): The breeding behavior of Gammarus duebeni. Hydrobiologia, 121:45-50.

WARD, P. I. (1986): A comparative field study of the breeding behavior of a stream and a pond population of Gammarus pulex (Amphipoda). Oikos, $46: 29-36$.

WiLDISH, D. J. (1982) : Evolutionary ecology of reproduction in gammaridean Amphipoda. Int. J. Invert. Rep., $5: 1-19$.

（著者：草野晴美・草野 保 - 渡辺泰徳, 東京都立大 学理学部生物学教室, $\boldsymbol{\top} 158$ 東京都世田谷区深沢 2-1-1; Harumi Kusano, Tamotsu Kusano and Yasunori Watanabe, Department of Biology, Tokyo Metropolitan University, Fukazawa 2-1-1, Setagaya -ku, Tokyo 158)

Received : 26 September 1986 Accepted : 20 February 1987 